\title{
Heavy metal accumulation in shrubs used in roadside planting
}

\author{
Beklayalı N. ${ }^{1^{*}}$, and Gur M. ${ }^{2}$ \\ ${ }^{1}$ Department of Landscape Architecture, Kastamonu University Faculty of Engineering and Architecture, Kuzeykent, Kastamonu, \\ Turkey \\ 2Department of Forest Industrial Engineering, Kastamonu University Faculty of Forestry, Kuzeykent, Kastamonu, Turkey \\ Received: 25/04/2019, Accepted: 13/09/2020, Available online: 15/09/2020 \\ *to whom all correspondence should be addressed: e-mail: nbelkayali@kastamonu.edu.tr \\ https://doi.org/10.30955/gnj.03140
}

\section{Graphical abstract}

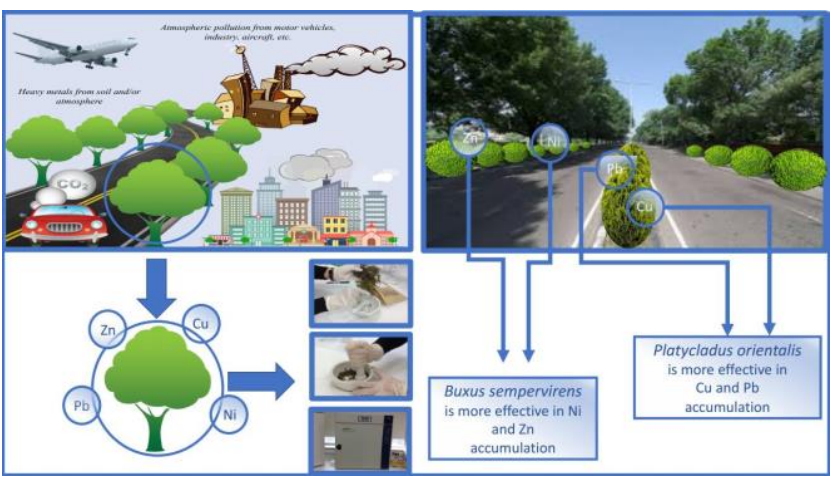

\section{Abstract}

The aim of this study is to determine the shrub species which can be used as the biomonitor of air pollution originating mainly from the traffic and could provide the opportunity to increase the air quality in urban areas. To this end, Berberis thunbergii, Buxus sempervirens, Juniperus horizontalis, and Platycladus orientalis, mostly preferred species for roadside plantations, were chosen for the study. First, three regions with heavy traffic intensities were determined. Next, the levels of 4 heavy metals were examined by using Inductively Coupled Plasma-Optical Emission Spectrometry. The results obtained indicate that since the deposition of $\mathrm{Cu}$ and $\mathrm{Zn}$ is more in the leaves and barks of four species, these shrub species are more effective in the accumulation of $\mathrm{Cu}$ and $\mathrm{Zn}$. Furthermore, the results of the study show that Platycladus orientalis is more effective in $\mathrm{Cu}$ and $\mathrm{Pb}$ accumulation, while Buxus sempervirens is more effective in terms of $\mathrm{Ni}$ and $\mathrm{Zn}$ accumulation. Determining high levels of traffic-originated heavy metals of $\mathrm{Cu}, \mathrm{Pb}$ and $\mathrm{Zn}$, particularly in the leaves of Platycladus orientalis in the city center indicates that air pollution is more intense in the city center and that Platycladus orientalis can be used as a biomonitor for traffic-originated air pollution.

Keywords: Air pollution, heavy metal accumulation, shrub, roadside plantation.

\section{Introduction}

It was stated in "World Urbanization Prospects" published by the UN that $55 \%$ of the world population lives in cities as of 2017. With the increase in urbanization, environmental problems increase and new cities that are estranged from nature emerge (Karagulian et al., 2015). While the increase in urbanization due to increasing population causes ecosystem degradation in cities, open and green areas between the structure masses contributes positively to the quality of mental and physical life of the people in cities by playing an important part in the equalization of the relationship between human beings and the nature (Belkayalı and Güloğlu, 2019; Belkayalı and Ayan, 2018; Brown et al., 2014; Richards et al., 2017; Ummeh and Toshio, 2017). Plants that are used in roads which determine the direction of city's development, provide such contributions such as reducing the noise, creating a living space for wildlife, providing microclimate as well as providing aesthetic contributions such as setting a background for architectural structure of the city and screening the undesired sceneries (Forman, 2000; Kollarou and Kollaros, 2014; Perez et al., 2016; Singh et al., 2014). Urban roadside plantation takes on an important task in increasing the environmental quality by absorbing airsourced pollutants (particulate matters, heavy metals, etc.), beyond all of these contributions.

Many pollutant matters emerge from exhaust gases, car wheels, vehicles and the vehicle abrasions in city roads. Barium (Ba), Cadmium (Cd), Chromium (Cr), Copper (Cu), Iron (Fe), Nickel (Ni), Lead (Pb) and Zinc ( $\mathrm{Zn})$ are among these pollutant matters (Dadea et al., 2016; Fosu-Mensah et al., 2017; Ogundele et al., 2012; Pugh et al., 2002). In recent years, lichens (Conti and Cecchetti, 2001), the leaves of tall plants (Aboal et al., 2004; Ceburnis and Steinnes, 2000; Probst et al., 2009) and barks of trunks (Mandiwana et al., 2006; Sawidis et al., 2011) have been used as biomonitors in order to monitor the traffic-originated air pollution. Furthermore, deciduous plant species along with evergreen plants, notably coniferous ones, are regarded as decent options for disposing of traffic-originated pollutions (Ceburnis and Steinnes, 2000). 
It is important to determine the heavy metal concentrations in plants not only for monitoring the air quality and for disposing the heavy metals in the air by the plants, but also for determining the possibilities of using them as a device for increasing the air quality. As a consequence, many studies were conducted on the heavy metal accumulations in plants (Dadea et al., 2016; Ekmekyapar et al., 2012; Fosu-Mensah et al., 2017; Levy et al., 1999; Ogundele et al., 2012; Opaluwa et al., 2012; Pugh et al., 2002; Rahul and Jain, 2016). These studies, however, mostly focused on tree species and the number of studies on shrub species are limited. Yet, shrub species are plants in which exhaust-sourced heavy metal accumulation can easily be monitored due to their such characteristics as growing faster and being closer to the exhaust ports because of their small size, and these species can be used even in limited areas. Shrubs are more preferred, especially in cities, to meet more community needs in small areas and to provide more effective use of the low-square meter green areas. That is the reason why the studies on shrubs are of more importance.

Therefore, it is important that the shrub species which can be an indicator of air pollution, one of the most important problems experienced in cities, be identified, and that the use of these species in urban road planting be ensured. And also, the lack of these type of studies increases the importance of this study.

The aims of this study can be expressed as: (1) researching the opportunity to use shrubs as a means of monitoring and increasing the air quality, (2) determining and comparing the heavy metal concentrations that were accumulated in the leaves of chosen species, (3) determining the difference between the amounts of heavy metals that were accumulated in leaves and barks in highdensity traffic areas, (4) revealing the opportunities to use the species which has the most heavy metal accumulation in roadside plantation.

With this purpose, of the shrub species that are preferred the most in the roadside plantation in many regions of Turkey, 4 species, Berberis thunbergii (Japanese barberry), Buxus sempervirens (common box), Juniperus horizontalis (creeping juniper), Platycladus orientalis (oriental arborvitae) were chosen and leaf samples were taken in order to determine the accumulation of heavy metals such as $\mathrm{Cu}, \mathrm{Pb}, \mathrm{Ni}, \mathrm{Zn}$ in the shrubs, depending on the changes in traffic density. Furthermore, for the determination of whether or not there is a change in the heavy metal accumulation ratios in the leaves and barks, leaf and bark samples were taken from the region where the traffic is most dense.

\section{Materials and methods}

\subsection{Materials}

The main material of the study consists of 4 shrub species; Berberis thunbergii, Buxus sempervirens, Juniperus horizontalis, Platycladus orientalis, the most preferred shrubs in the roadside plantation in Turkey. Within the scope of the study, the samples were collected from the city center where the traffic is dense, from Kuzeykent neighborhood where the traffic is not so dense but has dense usage rate and from the immediate surrounding of the city where there is almost no traffic density (Figure 1).

\subsection{The Characteristics of the study area}

Kastamonu, a city within the borders of Black Sea Region, was chosen as the study area (Figure 1). Latitude and longitude coordinates of the city are: 41.3766, 33.7765 (Kastamonu Map and Coordinates, 2018). According to the data from the Turkish Statistical Institute (TSI), the population of Kastamonu city center was 145.754 in 2017 (TSI, 2018). While Kastamonu city center had a population of 67.093 in 1965, its population has undergone a dramatic increase of $117 \%$ within 52 years. This increase in the population has negatively affected the city's ecosystem which has an important place in the natural and cultural source values. Kastamonu possesses an ancient history, and archaeological excavations and surface explorations indicate that the region witnessed settlements in Paleolithic, Neolithic, Chalcolithic periods to early Bronze Age without any interruption (Yıldız, 2013). Furthermore, forest lands of Kastamonu constitute $66.2 \%$ of the total land (GDF, 2015). When the number of vehicles that cause traffic density in the city center of Kastamonu was examined, it was seen that there were 128,663 registered vehicles according to the data of 2017 (TSI, 2018). In the measurements of The Ministry of Environment and Urbanization about the air quality that was conducted on city basis, there weren't any days that exceeded the limit value of Sulfur dioxide $\left(\mathrm{SO}_{2}\right)$ concentrations according to the values of World Health Organization and the number of days that exceeded the limit value of particulate matter (PM10) were determined as 149 (Chamber of Environmental Engineers, 2018).

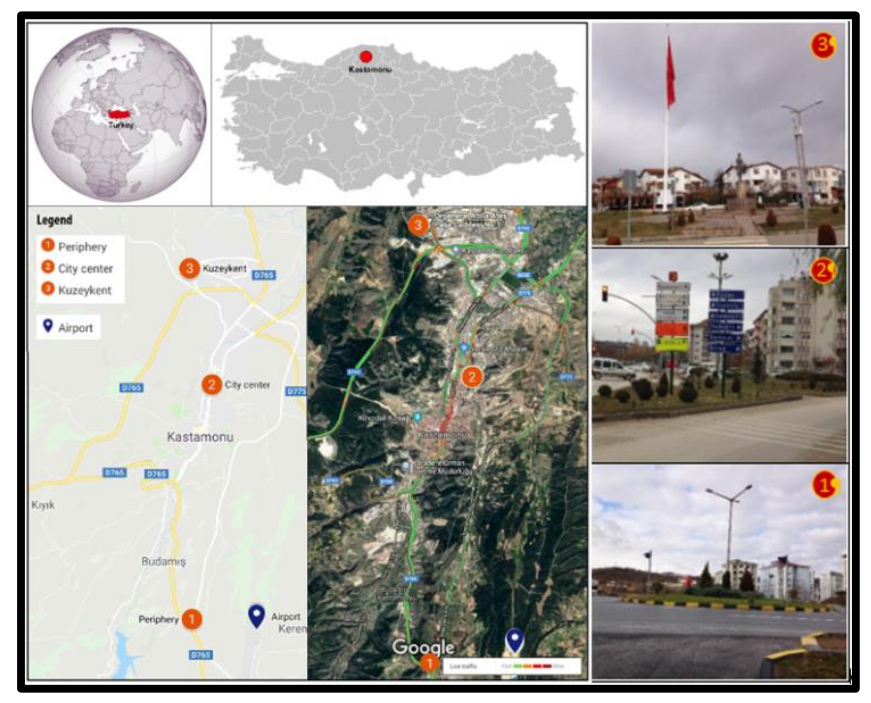

Figure 1. Location map of the study area and photographs of sampling points. Source: Mapdata (C) 2019 Google

(https://www.google.com/maps/@41.397765,33.803447, 13z). Imagery @2019 CNES/Airbus, DigitalGlobe, Landsat/Copernicus, Map data (C2019 Google 


\subsection{Methods}

The leaves of the plants in 3 study areas and the barks of them in the city center were collected with the help of shear and glove, without touching by hands. Leaf samples were collected at the end of the growing season from plants that spent 1 growing season in the same region. Thus, it was aimed to determine the heavy metal accumulation in samples for one growing season. The collected leaf and bark samples were labeled by bagging them separately. The heavy metal analyses were conducted in the laboratories of Kastamonu University Central Research Laboratory Application and Research Center. The values that were obtained within the scope of the study were evaluated by comparing the amount of heavy metal that were typically found in the plants which were given in Table 1 and the amount of allowed heavy metal in the plants which was determined by WHO.

Table 1. Typical levels for heavy metals in plants (Hajar et al., 2014)

\begin{tabular}{cccc}
\hline Heavy metals & $\begin{array}{c}\text { Typical levels for heavy } \\
\text { metals in plants }(\mu \mathrm{g} / \mathrm{g})\end{array}$ & $\begin{array}{c}\text { WHO permissible value of } \\
\text { plant }(\mu \mathrm{g} / \mathrm{g})\end{array}$ & Phytotoxic $(\mu \mathrm{g} / \mathrm{g})$ \\
\hline Copper $(\mathrm{Cu})$ & $0.04-4.58$ & 10 & $20-100$ \\
\hline Lead $(\mathrm{Pb})$ & 0.3 & 2 & $30-300$ \\
\hline Nickel $(\mathrm{Ni})$ & $0.01-0.37$ & 10 & $>100$ \\
\hline Zinc $(\mathrm{Zn})$ & $0.1-16$ & 0.60 & \\
\hline
\end{tabular}

*Target values are specified to indicate desirable maximum levels of elements in unpolluted soils

Table 2. Heavy metal concentrations (ppm $(\mu \mathrm{g} / \mathrm{g})$ ) in four shrub species leaves at each site

\begin{tabular}{|c|c|c|c|c|c|c|c|c|c|c|c|c|c|}
\hline \multirow{2}{*}{\multicolumn{2}{|c|}{ Shrub species }} & \multicolumn{4}{|c|}{ Periphery } & \multicolumn{4}{|c|}{ City center } & \multirow{2}{*}{\multicolumn{4}{|c|}{$\begin{array}{c}\text { Kuzeykent district } \\
\text { Concentrations }(\mathrm{ppm}(\mu \mathrm{g} / \mathrm{g}))\end{array}$}} \\
\hline & & \multicolumn{4}{|c|}{ Concentrations (ppm $(\mu \mathrm{g} / \mathrm{g}))$} & \multicolumn{4}{|c|}{ Concentrations (ppm $(\mu \mathrm{g} / \mathrm{g}))$} & & & & \\
\hline & & $\mathrm{Cu}$ & $\mathrm{Pb}$ & $\mathrm{Ni}$ & $\mathrm{Zn}$ & $\mathrm{Cu}$ & $\mathrm{Pb}$ & $\mathrm{Ni}$ & $\mathrm{Zn}$ & \multirow{2}{*}{$\mathrm{Cu}$} & \multirow{2}{*}{ Pb } & \multirow{2}{*}{$\frac{\mathbf{N i}}{1,332}$} & \multirow{2}{*}{$\begin{array}{c}\text { Zn } \\
8,943\end{array}$} \\
\hline \multirow{3}{*}{$\begin{array}{l}\text { Berberis } \\
\text { thunbergii }\end{array}$} & mean & 5,128 & 1,771 & 1,697 & 12,371 & 8,173 & 2,302 & 1,231 & 7,402 & & & & \\
\hline & $\mathrm{sd}$ & 0.433 & 0.228 & 0.136 & 1.231 & 0.330 & 0.440 & 0.156 & 0.339 & 0.325 & 0.723 & 0.393 & 0.445 \\
\hline & rsd & 0.845 & 1.288 & 0.798 & 0.995 & 0.404 & 1.914 & 1.269 & 0.458 & 0.801 & 2.764 & 2.950 & 0.498 \\
\hline \multirow{3}{*}{$\begin{array}{c}\text { Buxus } \\
\text { sempervirens }\end{array}$} & mean & 10,73 & 2,729 & 1,627 & 26,899 & 8,068 & 2,929 & 3,83 & 5,777 & 7,031 & 3,233 & 2,832 & 7,755 \\
\hline & sd & 0.476 & 0.091 & 0.117 & 2.176 & 0.444 & 0.672 & 0.498 & 0.476 & 0.157 & 0.158 & 0.334 & 0.939 \\
\hline & $\mathrm{rsd}$ & 0.444 & 0.335 & 0.719 & 0.809 & 0.551 & 2.294 & 1.300 & 0.823 & 0.223 & 0.490 & 1.181 & 1.211 \\
\hline \multirow{3}{*}{$\begin{array}{c}\text { Juniperus } \\
\text { horizontalis }\end{array}$} & mean & 5,02 & 1,252 & 0,665 & 4,985 & 4,65 & 2,163 & 1,507 & 5,564 & 4,014 & 2,298 & 1,338 & 7,362 \\
\hline & $\mathrm{sd}$ & 0.609 & 0.146 & 0.254 & 0.165 & 0.389 & 0.491 & 0.359 & 1.021 & 0.612 & 0.366 & 0.290 & 0.238 \\
\hline & $\mathrm{rsd}$ & 1.214 & 1.167 & 3.815 & 0.331 & 0.836 & 2.270 & 2.385 & 1.834 & 1.525 & 1.592 & 2.169 & 0.323 \\
\hline \multirow{3}{*}{$\begin{array}{l}\text { Platycladus } \\
\text { orientalis }\end{array}$} & mean & 3,78 & 3,048 & 1,261 & 8,377 & 11,759 & 3,494 & 2,041 & 13,406 & 7,779 & 3,216 & 2,178 & 9,294 \\
\hline & $\mathrm{sd}$ & 0.618 & 0.588 & 0.168 & 0.306 & 0.991 & 0.179 & 0.081 & 0.975 & 0.559 & 0.398 & 0.315 & 0.419 \\
\hline & rsd & 1.635 & 1.930 & 1.331 & 0.365 & 0.843 & 0.512 & 0.397 & 0.728 & 0.719 & 1.238 & 1.448 & 0.451 \\
\hline
\end{tabular}

\subsubsection{Heavy metal analysis}

The concentrations $(\mu \mathrm{g} / \mathrm{g}$ ) of $\mathrm{Cu}, \mathrm{Pb}, \mathrm{Ni}$ and $\mathrm{Zn}$ in the samples were analyzed by using Inductively Coupled Plasma-Optical Emission Spectrometry (ICP-OES) with an Spectro Blue/Spectro. The samples were firstly homogenized sterilely by milling in a mill (Isolab). It was then dehydrated using the Microwave Burning System (Nüve FN 120 Dry Heat sterilizer/Ovens Milestone) (Figure 2).

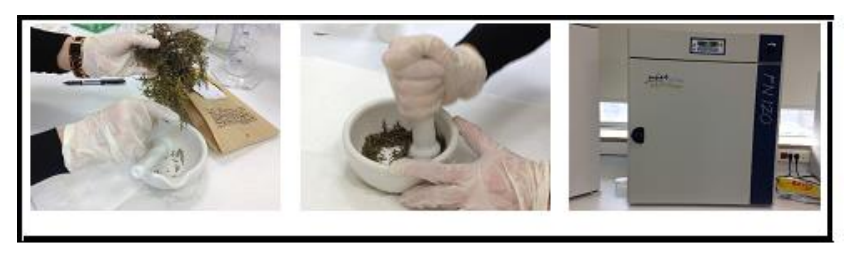

Figure 2. Images of sample preparation

$0.5 \mathrm{~g}$ of every sample was taken and then mixed with $7 \mathrm{~mL}$ $\mathrm{HNO}_{3}(67 \% \mathrm{v} / \mathrm{v})$ and $1 \mathrm{~mL} \mathrm{H} \mathrm{O}_{2}(30 \% \mathrm{v} / \mathrm{v})$ in reference to the application information of the device. To prepare blank solution, $7 \mathrm{~mL}$ of $\mathrm{HNO}_{3}(67 \% \mathrm{v} / \mathrm{v})$ and $1 \mathrm{~mL}$ of $\mathrm{H}_{2} \mathrm{O}_{2}(30 \%$ $\mathrm{v} / \mathrm{v}$ ) were placed in the empty microwave vessel and then were burned. The brims of the microwave containers were tightly closed and the temperature program for burning was adjusted. According to the temperature program, the samples were adjusted to $200{ }^{\circ} \mathrm{C}$ at 45 bar for the first 15 minutes, then were kept constant at $200^{\circ} \mathrm{C}$ for 15 minutes. After the process, the solutions were cooled to room temperature. The samples which were then dissolved were taken up in flask and completed to $50 \mathrm{~mL}$ with ultrapurified water.

The standard stock solution (10 mg/L, periodic table mix 1 , Sigma Aldrich) was used to prepare the calibration standards. The prepared samples and calibration solutions were analyzed on a SpectroBlue brand ICP-OES device.

\subsubsection{Statistical analysis}

Statistical calculations were made to determine whether there is a significant difference between the plant species and study areas selected within the scope of the study in terms of evaluating heavy metal accumulation. The obtained data were evaluated with Analysis of VarianceANOVA in SPSS 17.0 package program and the results were evaluated reciprocatively in terms of heavy metal type, region, and plant species. For analyzing whether the independent variables of plant 
species (Berberis thunbergii, Buxus sempervirens, Juniperus horizontalis and Platycladus orientalis) and region (City center, Kuzeykent district, periphery) have a statistically significant effect on the concentration distribution of four heavy metals $(\mathrm{Cu}, \mathrm{Pb}, \mathrm{Ni}$ and $\mathrm{Zn})$, Analysis of VarianceANOVA was used. Whether or not there is a significant difference between the obtained results were determined according to the significance level of 0.05 .

Table 3. The effect of plant species and the region on the concentration distribution of four heavy metals

\begin{tabular}{|c|c|c|c|c|c|c|c|c|c|c|c|}
\hline & & \multicolumn{4}{|c|}{ Plant species } & \multicolumn{6}{|c|}{ Location } \\
\hline & & $\begin{array}{l}\text { Sum of } \\
\text { Squares }\end{array}$ & df & $\begin{array}{l}\text { Mean } \\
\text { Square }\end{array}$ & $\mathbf{F}$ & Sig. & $\begin{array}{l}\text { Sum of } \\
\text { Squares }\end{array}$ & df & $\begin{array}{l}\text { Mean } \\
\text { Square }\end{array}$ & $\mathbf{F}$ & Sig. \\
\hline \multirow{3}{*}{$\mathrm{Cu}$} & $\begin{array}{c}\text { Between } \\
\text { Groups }\end{array}$ & 91,862 & 3 & 30,621 & 6,696 & ,001* & 40,626 & 2 & 20,313 & 3,393 & ,046* \\
\hline & $\begin{array}{l}\text { Within } \\
\text { Groups }\end{array}$ & 146,336 & 32 & 4,573 & & & 197,573 & 33 & 5,987 & & \\
\hline & Total & 238,198 & 35 & & & & 238,198 & 35 & & & \\
\hline \multirow{3}{*}{$\mathrm{Pb}$} & $\begin{array}{c}\text { Between } \\
\text { Groups }\end{array}$ & 10,602 & 3 & 3,534 & 29,979 & ,000* & 2,789 & 2 & 1,395 & 3,972 & ,028* \\
\hline & $\begin{array}{l}\text { Within } \\
\text { Groups }\end{array}$ & 3,772 & 32 & 0,118 & & & 11,586 & 33 & 0,351 & & \\
\hline & Total & 14,375 & 35 & & & & 14,375 & 35 & & & \\
\hline \multirow{3}{*}{$\mathrm{Ni}$} & $\begin{array}{c}\text { Between } \\
\text { Groups }\end{array}$ & 13,223 & 3 & 4,408 & 13,645 &, $000^{*}$ & 4,511 & 2 & 2,255 & 3,907 & ,030* \\
\hline & $\begin{array}{l}\text { Within } \\
\text { Groups }\end{array}$ & 10,337 & 32 & 0,323 & & & 19,05 & 33 & 0,577 & & \\
\hline & Total & 23,561 & 35 & & & & 23,561 & 35 & & & \\
\hline \multirow{3}{*}{$\mathrm{Zn}$} & $\begin{array}{c}\text { Between } \\
\text { Groups }\end{array}$ & 256,896 & 3 & 85,632 & 3,019 &, $044^{*}$ & 198,16 & 2 & 99,08 & 3,383 & ,046* \\
\hline & $\begin{array}{l}\text { Within } \\
\text { Groups }\end{array}$ & 907,798 & 32 & 28,369 & & & 966,534 & 33 & 29,289 & & \\
\hline & Total & 1164,69 & 35 & & & & 1164,694 & 35 & & & \\
\hline
\end{tabular}

*. The mean difference is significant at the 0.05 level.

Table 4. Post Hoc Test Table

\begin{tabular}{|c|c|c|c|c|c|c|c|c|c|}
\hline \multicolumn{5}{|c|}{ Plant species } & \multicolumn{5}{|c|}{ Location } \\
\hline $\begin{array}{l}\text { Dependent } \\
\text { Variable }\end{array}$ & $\begin{array}{l}\text { (I) Plant } \\
\text { species }\end{array}$ & $\begin{array}{l}\text { (J) Plant } \\
\text { species }\end{array}$ & Std. Error & Sig. & $\begin{array}{c}\text { Dependent } \\
\text { Variable }\end{array}$ & $\begin{array}{c}\text { (I) } \\
\text { Location }\end{array}$ & $\begin{array}{c}\text { (J) } \\
\text { Location }\end{array}$ & Std. Error & Sig. \\
\hline \multirow{3}{*}{$\mathrm{Cu}$} & $\begin{array}{c}\text { Buxus } \\
\text { sempervirens }\end{array}$ & $\begin{array}{c}\text { Berberis } \\
\text { thunbergii }\end{array}$ & 1,0080801 &, $041^{*}$ & \multirow{3}{*}{$\mathrm{Cu}$} & \multirow{3}{*}{$\begin{array}{l}\text { City } \\
\text { center }\end{array}$} & \multirow{3}{*}{ Kuzeykent } & \multirow{3}{*}{ 9989199, } & \multirow{3}{*}{, $020^{*}$} \\
\hline & $\begin{array}{c}\text { Juniperus } \\
\text { horizontalis }\end{array}$ & $\begin{array}{c}\text { Buxus } \\
\text { sempervirens }\end{array}$ & 1,0080801 &, $002 *$ & & & & & \\
\hline & $\begin{array}{l}\text { Platycladus } \\
\text { orientalis }\end{array}$ & $\begin{array}{c}\text { Juniperus } \\
\text { horizontalis }\end{array}$ & 1,0080801 & ,016* & & & & & \\
\hline \multirow{4}{*}{$\mathrm{Pb}$} & $\begin{array}{c}\text { Berberis } \\
\text { thunbergii }\end{array}$ & $\begin{array}{c}\text { Buxus } \\
\text { sempervirens }\end{array}$ & 1618557 &, $000 *$ & \multirow{4}{*}{$\mathrm{Pb}$} & \multirow{2}{*}{ Periphery } & \multirow{2}{*}{$\begin{array}{l}\text { City } \\
\text { center }\end{array}$} & \multirow{2}{*}{,2418952 } & \multirow{2}{*}{,038* } \\
\hline & $\begin{array}{c}\text { Buxus } \\
\text { sempervirens }\end{array}$ & $\begin{array}{c}\text { Juniperus } \\
\text { horizontalis }\end{array}$ & 1618557 &, $000 *$ & & & & & \\
\hline & $\begin{array}{c}\text { Juniperus } \\
\text { horizontalis }\end{array}$ & $\begin{array}{c}\text { Platycladus } \\
\text { orientalis }\end{array}$ & 1618557 & ,000* & & \multirow{2}{*}{ Kuzeykent } & \multirow{2}{*}{ Periphery } & \multirow{2}{*}{ 2418952 } & \multirow{2}{*}{, $012^{\prime}$} \\
\hline & $\begin{array}{l}\text { Platycladus } \\
\text { orientalis }\end{array}$ & $\begin{array}{c}\text { Berberis } \\
\text { thunbergii }\end{array}$ & 1618557 & ,000* & & & & & \\
\hline \multirow{3}{*}{$\mathrm{Ni}$} & $\begin{array}{c}\text { Berberis } \\
\text { thunbergii }\end{array}$ & $\begin{array}{c}\text { Buxus } \\
\text { sempervirens }\end{array}$ & 2679329 & ,000* & \multirow{3}{*}{$\mathrm{Ni}$} & \multirow{3}{*}{ Periphery } & \multirow{3}{*}{$\begin{array}{l}\text { City } \\
\text { center }\end{array}$} & \multirow{3}{*}{ 3101840 } & \multirow{3}{*}{, $011^{*}$} \\
\hline & $\begin{array}{c}\text { Buxus } \\
\text { sempervirens }\end{array}$ & $\begin{array}{c}\text { Platycladus } \\
\text { orientalis }\end{array}$ & 2679329 & ,007* & & & & & \\
\hline & $\begin{array}{c}\text { Juniperus } \\
\text { horizontalis }\end{array}$ & $\begin{array}{c}\text { Buxus } \\
\text { sempervirens }\end{array}$ & 2679329 &, $000 *$ & & & & & \\
\hline \multirow[t]{2}{*}{$\mathrm{Zn}$} & \multirow{2}{*}{$\begin{array}{c}\text { Buxus } \\
\text { sempervirens }\end{array}$} & \multirow{2}{*}{$\begin{array}{c}\text { Juniperus } \\
\text { horizontalis }\end{array}$} & \multirow[t]{2}{*}{2,5108071} & \multirow[t]{2}{*}{, $026 *$} & \multirow[t]{2}{*}{$\mathrm{Zn}$} & Periphery & $\begin{array}{c}\text { City } \\
\text { center }\end{array}$ & 2,2094085 &, $027^{*}$ \\
\hline & & & & & & Kuzeykent & Periphery & 2,2094085 & ,036* \\
\hline
\end{tabular}

\footnotetext{
*. The mean difference is significant at the 0.05 level.
} 


\section{Results and Discussion}

\subsection{Results}

The mean values of $\mathrm{Cu}, \mathrm{Pb}, \mathrm{Ni}$ and $\mathrm{Zn}$, concentrations in the studied leaves were summarized as ppm ( $\mu \mathrm{g} / \mathrm{g})$ in Table 2. It was seen that heavy metal content differs according to the area of the taken sample.

The highest metal amounts of Berberis thıunbergii leaves were detected for $\mathrm{Cu}$ in city center, for $\mathrm{Pb}$ in Kuzeykent district, and for $\mathrm{Ni}$ and $\mathrm{Zn}$ in periphery. The ranking of analyzed heavy metal concentration in Buxus sempervirens leaves were determined as follows: periphery> city center $>$ Kuzeykent district for $\mathrm{Cu}$, Kuzeykent district> city center $>$ periphery for $\mathrm{Pb}$; city center > Kuzeykent district> periphery for $\mathrm{Ni}$ and periphery $>$ Kuzeykent district $>$ city center for $\mathrm{Zn}$. The levels of heavy metals detected in Juniperus horizontalis leaves were ordered $\mathrm{Cu}>\mathrm{Zn}>\mathrm{Pb}>$ $\mathrm{Ni}$ for periphery, and $\mathrm{Zn}>\mathrm{Cu}>\mathrm{Pb}>\mathrm{Ni}$ for city center and Kuzeykent district. It was seen that among all values, the highest value for $\mathrm{Zn}$ was at Kuzeykent district. The ranking of analyzed heavy metal concentration in Platycladus orientalis leaves were determined as follows: city center > Kuzeykent district $>$ periphery for $\mathrm{Cu}, \mathrm{Pb}$ and $\mathrm{Zn}$; Kuzeykent district> city center $>$ periphery for $\mathrm{Ni}$. (Table 2 ). As seen Table 2, Berberis thunbergii, Buxus sempervirens, Juniperus horizontalis and Platycladus orientalis leaves were behaved as a good collector for analyzed metals especially $\mathrm{Cu}$ and $\mathrm{Zn}$.

According to the results of analyses, the highest $\mathrm{Cu}$ and $\mathrm{Pb}$ values were found in Platycladus orientalis $(11,759 \mathrm{ppm}$ $(\mu \mathrm{g} / \mathrm{g}) ; 3,494 \mathrm{ppm}(\mu \mathrm{g} / \mathrm{g}))$ in city center, the highest $\mathrm{Ni}$ value was found in Buxus sempervirens $(3,83 \mathrm{ppm}(\mu \mathrm{g} / \mathrm{g})$ ) in city center and the highest $\mathrm{Zn}$ value was found in Buxus sempervirens $(26,899 \mathrm{ppm}(\mu \mathrm{g} / \mathrm{g}))$ which was taken from the periphery (Table 2 ).

It was determined that the independent variables plant species (Berberis thunbergii, Buxus sempervirens, Juniperus horizontalis and Platycladus orientalis) and region (City center, Kuzeykent district, periphery) have a statistically significant effect on the concentration distribution of four heavy metals ( $\mathrm{Cu}, \mathrm{Pb}, \mathrm{Ni}$ and $\mathrm{Zn}$ ) according to the significance level of 0.05 (Table 3).

The result of the Post Hoc Test according to the significance level of 0.05 showed that while $\mathrm{Cu}, \mathrm{Pb}$ and $\mathrm{Ni}$ concentration distribution differ significantly in all four shrub species, $\mathrm{Zn}$ concentration differ significantly only between Buxus sempervirens and Juiperus horizontalis (Table 4).

When the heavy metals analyses in the bark and leaves of the Berberis thunbergii, Buxus sempervirens and Platycladus orientalis were compared, Cu was significantly in higher concentrations in the bark. It was determined that in the bark of Berberis thunbergii and Buxus sempervirens, level of $\mathrm{Zn}$ was higher than its leaves had. Also, the study results showed that the barks of Juniperus horizontalis contained more $\mathrm{Ni}$ than its leaves did, and that the level of $\mathrm{Pb}$ in the barks of Buxus sempervirens and Platycladus orientalis were higher than their leaves (Figure 3).

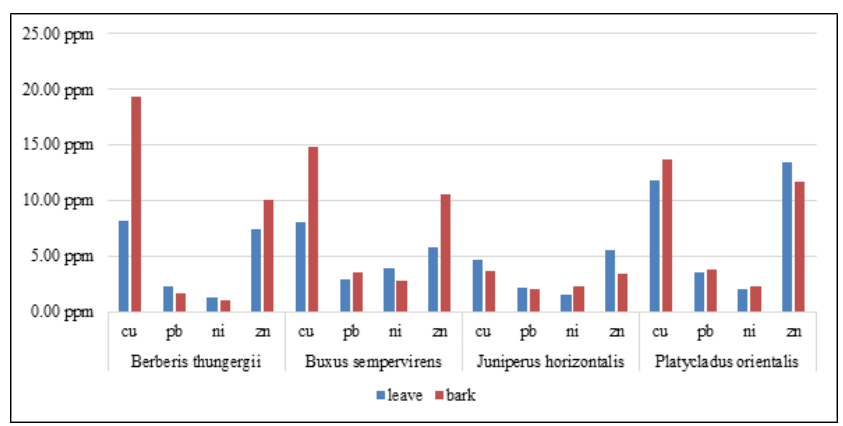

Figure 3. Heavy Metal Concentrations (ppm, $(\mu \mathrm{g} / \mathrm{g})$ ) in the barks and leaves of four shrub species in the city center

When the amounts of heavy metal that are typically found in the plants, the amounts of allowed heavy metal in the plants which was determined by WHO, phytotoxic effect levels and the values that were obtained from the leaves as a result of the study were compared; it was determined that the amount of $\mathrm{Cu}$ in Platycladus orientalis in the city center and Buxus sempervirens outside of the city were higher than the allowed value $10 \mu \mathrm{g} / \mathrm{g}$ ) of WHO. While $\mathrm{Pb}$ and $\mathrm{Ni}$ values were determined to be higher than the typical level $(0.3 \mu \mathrm{g} / \mathrm{g} ; 0.37 \mu \mathrm{g} / \mathrm{g})$ in all of the four species, it was observed that $\mathrm{Pb}$ value was higher than the value that was determined by WHO ( $2 \mu \mathrm{g} / \mathrm{g}$ ) except for Juniperus horizontalis. It was observed that $\mathrm{Zn}$ value was higher than the allowed level $(0.60 \mu \mathrm{g} / \mathrm{g})$ that was determined by WHO in all of the four species. As a result of the measurements, it was determined that none of the plants possessed a level of heavy metal that would cause a phytotoxic effect. According to the measurement results of samples that were taken from the barks of four plant species in the city center, it was determined that except for Juniperus horizontalis, the amount of $\mathrm{Cu}$ was much higher than the typical level $(4.58 \mu \mathrm{g} / \mathrm{g})$ and the allowed level $(10 \mu \mathrm{g} / \mathrm{g})$ determined by WHO and Berberis thunbergii was too close to the phytotoxic effect level $(20 \mu \mathrm{g} / \mathrm{g})$. $\mathrm{Pb}$ and $\mathrm{Ni}$ values were determined to be higher than the typical level $(0.3$ $\mu \mathrm{g} / \mathrm{g} ; 0.37 \mu \mathrm{g} / \mathrm{g}$ ) in all of the four species. It was observed that $\mathrm{Zn}$ value was higher than the allowed level $(0.60 \mu \mathrm{g} / \mathrm{g})$ of WHO in all of the four species, as it was also in leaves (Table 1).

\subsection{Discussion}

Air pollution is one of the most important problems that threaten human health. Several studies were conducted in order to solve this problem. A part of these studies are comprised of studies that search for the possibility of using plants for monitoring and increasing the air quality. One of the factors that cause air pollution is heavy metals, and a large part of these heavy metals are oscillated due to human activities. Highways, mine sites, landfills and especially urban areas where human activities are dense are the important sources of heavy metals that are oscillated to the air. The studies conducted so far demonstrated that the heavy metal accumulation is seen more in plants in these areas (Dadea et al., 2016; Ekmekyapar et al., 2012; Fosu-Mensah et al., 2017; Ogundele et al., 2012; Opaluwa et al., 2012; Pugh et al., 
2002; Rahul and Jain, 2016). In this study, Kastamonu city center selected as the study area since urban areas are one of the important sources of heavy metals. In order to determine the effect of heavy metal sources on plants, 4 shrub species and 3 areas with different usage densities were selected. The reasons for choosing shrub species in the study are that the exhaust pipes of the vehicles that cause heavy metal emission, and that the shrubs are at approximately the same height and therefore it is predicted that they were exposed to heavy metals more, and that the selected shrub species have not been studied in studies on this subject yet.

There are different heavy metal sources in 3 different areas where samples are collected. Samples were taken from plants at approximately the same distance from the road in order to demonstrate the effect of heavy metal sources caused by traffic on plants more clearly. Similar approaches have been observed in studies that were conducted on tree species (Ataabadi et al., 2010; Fosu-Mensah et al., 2017; Liang et al., 2017; Ogundele et al., 2015; Sulaiman and Hamzah, 2018; Ugolini et al., 2013).

One of the studies that were conducted in order to determine which plants to be used as a biomonitor in the determination of air quality is the study of Pugh et al. (2002). Pugh et al. (2002) states that Ledum is a decent indicator plant for $\mathrm{Pb}$, and that Salix is a good indicator plant for $\mathrm{Zn}$ and $\mathrm{Cd}$. In this study which was conducted in Kastamonu, Berberis thunbergii, Buxus sempervirens, Juniperus horizontalis, and Platycladus orientalis leaves and barks behaved as a good collector for analyzed metals especially $\mathrm{Cu}$ and $\mathrm{Zn}$. Also, among the four species tested in this study, levels of $\mathrm{Pb}$ and $\mathrm{Cu}$ in Platycladus orientalis and levels of $\mathrm{Zn}$ and $\mathrm{Ni}$ in Buxus sempervirens were the highest than the others. Therefore, Platycladus orientalis appears to be the most efficient accumulator of $\mathrm{Pb}$ and $\mathrm{Cu}$ among the four plants tested and may have the potential to be used as an indicator for $\mathrm{Pb}$ and $\mathrm{Cu}$ contamination in this region, while Buxus sempervirens appears as the most efficient accumulator of and indicator for $\mathrm{Zn}$ and $\mathrm{Ni}$.

Although many studies were conducted on the usage of plant leaves as a biomonitor, there is a limited number of studies that were conducted on using barks as a biomonitor. In their study, Sawidis et al. (2011) and Mandiwana et al. (2006) state that heavy metal retention is higher in barks than leaves. The results of the study in Kastamonu indicated that $\mathrm{Cu}$ value was higher in Berberis thunbergii, Buxus sempervirens and Platycladus orientalis barks compared to the leaves.

$\mathrm{Pb}$ is not one of the main elements for plants, and since there are generally low amounts of $\mathrm{Pb}$ in soil, $\mathrm{Pb}$ levels that are determined in plants are good indicators for the determination of air quality (Kocić et al., 2014; Liang et al., 2017; Pugh et al., 2002; Turer et al., 2001). Determining high amounts of $\mathrm{Pb}$ level in the barks and leaves of Platycladus orientalis indicates that Platycladus orientalis can be helpful for heavy metal retention and can be used as an indicator of air pollution.
Ugolini et al. (2013), Dam-o (2015), Dadea et al. (2016) and Sulaiman and Hamzah (2018) hypothesize that plants' metal deposition capacity is connected to the surrounding environmental characteristics and the distance of plants from the source of pollution. Liang et al. (2017) measured concentrations of heavy metals $(\mathrm{Cu}, \mathrm{Zn}, \mathrm{Pb}$ and $\mathrm{Cd})$ in leaves of twelve plant species from seven different locations in Shanghai, China. The results showed that the highest metal contents were found in the city center. Likewise, Sawidis et al. (2011) measured concentrations of four heavy metals in tree leaves and bark (Platanus orientalis L. and Pinus nigra Arn.,) from polluted and nonpolluted areas of three European cities (Salzburg, Belgrade and Thessaloniki). The results show that selected plants have a higher efficiency as bioindicator for urban pollution. Also, Fosu-Mensah et al. (2017) evaluated the levels and risk of heavy metal contamination in soils and vegetation around the Korle Lagoon area in Accra where burning of ewaste and cultivation of vegetables takes place. High accumulations of heavy metals were observed in the plants samples collected, with the concentrations of $\mathrm{Cu}, \mathrm{Pb}, \mathrm{Ni}$ and $\mathrm{Cd}$ exceeding their acceptable limits. As it was also stated in the study of Ogundele et al. (2012), the results of the study that was conducted in Kastamonu indicate that heavy metal accumulation is seen more in plants which are near to the source of pollution, that is, the places where vehicle traffic is dense, and thus, the amounts of $\mathrm{Cu}, \mathrm{Pb}$ and $\mathrm{Ni}$ were determined the highest in city center.

Furthermore, Dadea et al. (2016) and Ekmekyapar et al. (2012) state that $\mathrm{Cu}$ and $\mathrm{Zn}$ values are higher in the leaves of plants where traffic is dense, and that this can be an indication that these metals are in the air due to traffic. Within the scope of this study, it was determined that in the leaf samples of Platycladus orientalis in the city center where traffic is the densest, $\mathrm{Pb}, \mathrm{Cu}$ and $\mathrm{Zn}$ values were determined to be higher when compared to other species. In this context, it is possible that $\mathrm{Pb}, \mathrm{Cu}$ and $\mathrm{Zn}$ metals were in the air due to traffic density in the city center, and it was predicted that Platycladus orientalis could be used as a biomonitor for this situation.

Results of the study by Piczak et al. (2003) demonstrate that metal accumulation of birch, willow, lime and maple leaves have significant differences. It was determined that there is a significant difference in the $\mathrm{Cu}, \mathrm{Pb}, \mathrm{Ni}$ and $\mathrm{Zn}$ retention characteristic of 4 shrub species which was chosen within the scope of this study. Also, region have a statistically significant effect on the concentration distribution of four heavy metals.

The benefits (sound, scenery, noise screening, etc.) of roadside plantation in terms of decreasing the negative impacts that occur on roads were proven by the conducted studies (Forman, 2000; Perez et al., 2016; Kollarou and Kollaros, 2014; Singh et al., 2014). One of these benefits is that it helps decrease the usage of heavy metal concentration in the environment and fulfill the duty of screening.) Examining whether or not roadside plantation has an effect on the heavy metal accumulation in the agricultural lands in the sides of Trsihuli Highway which is between the cities of Trishuli and Kathmandu in Nepal, 
Zhang et al. (2012 stated that roadside plantation had an impact on decreasing the heavy metal concentrations in agricultural lands. The results of the study conducted in Kastamonu also supports the results of this study. Since roadside plants provide environmental utilizations to get less affected by heavy metals by retaining and thus screening the heavy metals that were oscillated to the air, using plants that have high levels of heavy metal retain characteristics in areas where the traffic is dense, has great importance for the increase of air quality.

Our studies in literature showed that so little is known about the biomonitoring by shrub species (Ataabandi et al., 2010; Fernandez Espinoza and Rossini Oliva, 2005; Hoodaji et al., 2012; Rosllsini Oliva and Mignorance, 2006) and effect of air pollution on shrubs. Ataabandi et al. (2010) stated that conifers were better than deciduous ones for airborne Fe and Ni contamination monitoring. In addition, according to the results of their study, it has been determined that $\mathrm{Fe}$ and $\mathrm{Ni}$ concentrations were more in Platycladus oreintalis leaves and Fe concentrations were more in Berberis vulgaris barks. Rezajenad (2009) tried to determine the effect of air pollution on the structures of plants especially in Platycladus orientalis. The observation results suggested that plants also Platycladus orientalis try to respond suitably by adjusting their metabolism so that minimum damage was done due to air pollutants. Also our study results showed that Platycladus orientalis is resistant to air pollution and can therefore be used as a biomonitor.

\section{Conclusion}

In the study which was conducted to determine the shrub species which can be used as the biomonitor of air pollution that originates especially from traffic and which could provide the opportunity to increase the air quality in urban areas, 4 shrub species which are mostly used for road plantation in Turkey was selected. Besides, 3 different areas with different human usage density were selected to demonstrate the effect of heavy metal sources caused by traffic on plants more clearly. Leaf samples were collected at the end of the growing season from plants that spent 1 growing season in the same region. In order to get accurate results from samples, the most attention was paid for sterilization during collection and analysis.

When the results of the study were evaluated, it was observed that the highest $\mathrm{Cu}$ and $\mathrm{Pb}$ values were determined in the leaves Platycladus orientalis that was taken from the city center, the highest $\mathrm{Zn}$ values were determined in the leaves of Buxus sempervirens that was taken from the periphery, and the highest $\mathrm{Ni}$ values were determined in the leaves of Buxus sempervirens that was taken from the city center. Furthermore, in the barks of Berberis thunbergii, Buxus sempervirens and Platycladus orientalis that were taken from the city center, $\mathrm{Cu}$ value was determined more when compared to the leaves. It was observed that in the chosen plant species, $\mathrm{Cu}$ and $\mathrm{Zn}$ accumulation was higher than other heavy metals. Therefore, Berberis thunbergii, Buxus sempervirens, Juniperus horizontalis, and Platycladus orientalis leaves and barks behaved as a good collector for analyzed metals especially $\mathrm{Cu}$ and $\mathrm{Zn}$. According to the analysis results, it was determined that Platycladus orientalis had the highest $\mathrm{Cu}$ and $\mathrm{Pb}$ retention characteristic and Buxus sempervirens had the highest $\mathrm{Ni}$ and $\mathrm{Zn}$ retention characteristic. Results indicate that Platycladus orientalis can be used as a biomonitor for $\mathrm{Cu}$ and $\mathrm{Pb}$ and Buxus sempervirens can be used as a biomonitor for $\mathrm{Ni}$ and $\mathrm{Zn}$.

According to the results of the research, the accumulation levels of 4 heavy metals ( $\mathrm{Cu}, \mathrm{Pb}, \mathrm{Zn}, \mathrm{Ni}$ ) showed a statistically significant difference in 4 shrub species and in 3 areas with different usage density. The results obtained within the scope of the study revealed that planning and implementation should be made in different areas in accordance with the characteristics and the needs of that area in order to ensure sustainable ecological protection and management. In this context, for the successful protection and management of the urban ecology, the species should be preferred according to the heavy metal resources and the density of these resources, especially in roadside vegetation. The preference of four bush species which were selected within the scope of the study for road planting will reduce the amount of $\mathrm{Cu}$ and $\mathrm{Zn}$ in the air in Kastamonu and in similar cities, and thus the desired air quality will be achieved. Also, they can be used as the biomonitors of traffic-originated pollution. Since $\mathrm{Cu}, \mathrm{Pb}$, and $\mathrm{Zn}$, traffic-originated heavy metals, were determined in higher levels in the leaves of Platycladus orientalis in the city center, it can be transcribed that air pollution is seen more in the city center than in any other study areas, and that Platycladus orientalis can be used as a biomonitor for traffic-originated air pollution according to study results. In addition, Buxus sempervirens can be suggested to be used in order to reduce the amount of $\mathrm{Zn}$ and $\mathrm{Ni}$ in the air.

\section{Acknowledgement}

This study is performed with KU-HIZDES/ 2015- 09 project results supported by Kastamonu University Coordinatorship of Scientific Research Projects.

\section{Disclosure statement}

No potential conflict of interest was reported by the authors.

\section{Funding}

This work was supported by Kastamonu University Coordinatorship of Scientific Research Projects [grant number KUHIZDES/2015-09].

\section{References}

Aboal J.R., Fernandez J.A. and Carballeira A. (2004). Oak leaves and pine needles as biomonitors of airborne trace elements pollution. Environmental and Experimental Botany, 51(3), 215-225.

Ataabadi M., Hoodaji M. and Najafi P. (2010), Heavy Metal Biomonitoring by Plants Grown in an Industrial Area of Isfahan Mabarakeh Steel Company. Journal of Environmental Studies, 35(53), 83-92.

Belkayalı N. and Güloğlu Y. (2019), Physical and social barriers for disabled urban park users: case study from Kastamonu, Turkey. Forestist, 69(1), 35-43. doi: 10.26650/forestist.2019.414498. 
Belkayalı N. and Ayan E. (2018), Classification of urban green spaces and parks: the case of Kastamonu. Research and Development on Social Sciences, Monographs and Studies of the Jagiellonian University, Institute of Public Affairs, Dorczak R., Lenart-Gansiniec R., Ruggiero C. and Ali İcbay M. (Eds.), Krokow, pp. 395-404.

Brown G., Schebella M.F. and Weber D. (2014), Using participatory GIS to measure physical activity and urban park benefits, Landscape and Urban Planning, 121, 34-44. https://doi.org/10.1016/j.landurbplan.2013.09.006.

Ceburnis D. and Steinnes E. (2000), Conifer needles as biomonitors of atmospheric heavy metal deposition: comparison with mosses and precipitation, role of the canopy. Atmospheric Environment, 34 (25), 4265-4271.

Chamber of Environmental Engineers. (2018), Chamber of Environmental Engineers Air Pollution Report 2017, [Internet]. Turkey; [cited 2018 June 1]. Available from: http://cmo.org.tr/resimler/ekler/2145efce8f89f52_ek.pdf.

Conti M.E. and Cecchetti G. (2001), Biological monitoring: lichens as bioindicators of air pollution assessment: a review, Environmental Pollution, 114, 471-492, https://doi.org/10.1016/S0269-7491(00)00224-4.

Dadea C., Bacchiocchi S.C., Rocca N., Mimmo T., Russo A. and Zerbe S. (2016), Heavy metal accumulation in urban soils and deciduous trees in the City of Bolzano, $\mathrm{N}$ Italy. Waldökologie, Landschaftsforschung und Naturschutz - Forest Ecology, Landscape Research and Nature Conservation, 15, 35-42.

Dam-o P. (2015), Examination of some heavy metal pollution in roadside plants using X-Ray Spectroscopy. University of Łódź Chair of Modelling Teaching Processes, Doctoral Dissertation, Poland, pp. 99.

Ekmekyapar F., Şabudak T. and Şeren G. (2012), Assessment of heavy metal contamination in soil and wheat (Triticum aestivum L.) plant around the Çorlu-Çerkezkoy highway in thrace region. Global NEST Journal, 14(4), 496-504.

Fernandez Espinoza A.J. and Rossini Oliva S. (2005), The composition and relationships between trace element levels in inhalable atmospheric praticles $\left(\mathrm{PM}_{10}\right)$ and in leaves of; Nerium oleander L. and Lantana camara L. Chemosphere, 62(10), 1665-1672.

Forman R.T.T. (2000), Estimate of the area affected ecologically by the road system in the United States, Conservation Biology, 14(1), 31-35.

Fosu-Mensah B.Y., Addae E., Yirenya-Tawiah D. and Nyame F. (2017), Heavy metals concentration and distribution in soils and vegetation at Korle Lagoon area in Accra, Ghana. Cogent Environmental Science, 3: 1405887, https://doi.org/10.1080/23311843.2017.1405887.

GDF. (2015), Distribution of areas, wealth and increase to provinces. Turkey Forest Asset 2015. Ministry of Forestry and Water Affairs, General Directorate of Forestry, [Internet]. Turkey; [cited 2018 June 10]. Available from: https:// www.ogm.gov.tr/ekutuphane/Yayinlar/T\%C3\%BCrkiye\%20Or man\%20Varl\%C4\%B1\%C4\%9F\%C4\%B1-2016-2017.pdf.

Hajar E.W.I., Sulaiman A.Z.B. and Sakinah A.M.M. (2014), Assessment of heavy metals tolerance in leaves, stems and flowers of Stevia rebaudiana plant. Procedia Environmental Sciences. 20(20), 386-393. doi: 10.1016/j.proenv.2014.03.049.

Karagulian F., Belis C.A., Dora C.F.C., Prüss-Ustün A.M., Bonjour S., Adair-Rohani H. and Amann M. (2015), Contributions to cities' ambient particulate matter (PM): A systematic review of local source contributions at global level, Atmospheric Environment, 120, 475-483.

Kocić K., Spasić T., Urośević M.A. and Tomaśević M. (2014), Trees as natural barriers against heavy metal pollution and their role in the protection of cultural heritage. Journal of Cultural Heritage, 15, 227-233.

Kollarou V. and Kollaros G. (2014), Management of roadside vegetation, road-island planting and slope cover. Proceedings of the 12th International Conference on Protection and Restoration of the Environment, Liakopoulos A., Kungolos A., Christodoulatos C., Koutsopsyros A. (Eds.), Skiathos Island, Greece, 29 June-3 July 2014, 647-652.

Levy D.B., Redente E.F. and Uphoff G.D. (1999), Evaluating the phytotoxicity of $\mathrm{Pb}-\mathrm{Zn}$ tailings to big bluestem (Andropogon gerardii vitman) and switchgrass (Panicum virgatum L.). Soil Science, 164(6), 363-375.

Liang C., Fangc H.L., Zhanga T.L., Wanga X.X. and Liu Y.D. (2017), Heavy metal in leaves of twelve plant species from seven different areas in Shanghai, China. Urban Forestry \& Urban Greening, 27, 390-398.

Mandiwana K., Resane T., Panichev N. and Ngobeni P. (2006), The application of tree bark as bio-indicator for the assessment of $\mathrm{Cr}(\mathrm{VI})$ in air pollution. Journal of Hazardous Materials, 137(2), 1241-1245.

Ogundele D.T., Adio A.A. and Oludele O.E. (2015), Heavy metal concentrations in plants and soil along heavy traffic roads in North Central Nigeria, Journal of Environmental \& Analytical Toxicology, 5, 6. doi: 10.4172/2161-0525.1000334.

Opaluwa O.D., Aremu M.O., Ogbo L.O, Abiola K.A., Odiba I.E., Abubakar M.M. and Nweze N.O. (2012), Heavy metal concentrations in soils, plant leaves and crops grown around dump sites in Lafia Metropolis, Nasarawa State, Nigeria. Advances in Applied Science Research, 3(2),780-784.

Perez M.A., Tegebu F.N. and Steenbergen F. (2016). Roadside planting in Ethiopia: turning a problem into an opportunity, Sustainability in Environment, 1(2), 98-115.

Piczak K., Sniewicz A. and Zyrnicki W. (2003), Metal concentrations in deciduous tree leaves from urban areas in Poland. Environmental Monitoring and Assessment, 86, 273287.

Probst A., Liu H., Fanjul M., Liao B. and Hollande E. (2009), Response of Vicia faba L. to metal toxicity on mine tailing substrate: geochemical and morphological changes in leaf and root. Environmental and Experimental Botany, 66(2), 297308.

Pugh R.E., Dick D.G. and Fredeen A.L. (2002), Heavy metal (Pb, Zn, $\mathrm{Cd}, \mathrm{Fe}$, and $\mathrm{Cu}$ ) contents of plant foliage near the anvil range Lead/Zinc Mine, Faro, Yukon Territory, Ecotoxicology and Environmental Safety, 52, 273-279. doi:10.1006/eesa.2002.2201.

Rahul J. and Jain M.K. (2016), Effect of heavy metals on some selected roadside plants and its morphological study: a review, American-Eurasian Journal of Agricultural \& Environmental Sciences, 16(1), 146-158.

Rezanejad F. (2009), Air pollution effects on structure, proteins and flavonoids in pollen grains of Thuja orientalis L. (Cupressaceae), Grana, 48, 205-212, doi: 10.1080/00173130902949417.

Richards D.R., Passy P. and Oh R.R. (2017), Impacts of population density and wealth on the quantity and structure of urban 
green space in tropical Southeast Asia. Landscape and Urban
Planning,
157,
553-560.
doi:

http://dx.doi.org/10.1016/j.landurbplan.2016.09.005.

Rossini Oliva S. and Mingorance M.D. (2006), Assesment of Airbone Heavy Metal Pollution by Aboveground Plants Parts, Chemosphere, 65(2), 177-182.

Sawidis T., Breuste J., Mitrovic M., Pavlovic P. and Tsigaridas K. (2011), Trees as bioindicator of heavy metal pollution in three European cities, Environmental Pollution, 159, 3560-3570.

Singh R.R., Goyal N. and Kaur N. (2014), Importance of roadside vegetation. International Journal of Progresses in Civil Engıneering (IJPCE), 1(1), 2394-4684.

Sulaiman F.R. and Hamzah H.A. (2018), Heavy metals accumulation in suburban roadside plants of a tropical area (Jengka, Malaysia). Ecological Processes, 7, 28. https://doi.org/10.1186/s13717-018-0139-3.

TSI. (2018), Turkish Statistical Institute Number of Motor Vehicles in Kastamonu Province. [Internet]. Turkey; [cited 2018 June 10]. Available from: https://biruni.tuik.gov.tr/medas/?kn=89\&locale=tr.

Turer D., Maynard J.B. and Sansalone J.J. (2001), Heavy metal contamination in soils of urban highways: comparison between runoff and soil concentrations at Cincinnati Ohio, Water, Air, \& Soil Pollution, 132, 293-314.

Ugolini F., Tognetti R., Raschi A. and Bacci L. (2013), Quercus ilex L. as bioaccumulator for heavy metals in urban areas: Effectiveness of leaf washing with distilled water and considerations on the trees distance from traffic, Urban Forestry \& Urban Greening, 12(4), 576-584.

Ummeh S. and Toshio K. (2017), Classification of urban parks and their regional characteristics in Dhaka City, Bangladesh. Journal of Environmental Science and Engineering, 6, 41-54.

United Nations. (2018), Urban Population. United Nations Population Division. World Urbanization Prospects: 2014 Revision, [Internet]. USA; [cited 2018 June 09]. Available from: https://data.worldbank.org/indicator/ SP.URB.TOTL.IN.ZS.

Kastamonu Map and Coordinates. (2018), [Internet]. Turkey; [cited 2018 June 10]. Available from: http://dunya.arztalep.com/tr-TR/kastamonu/ kastamonu-haritasi.aspx.

Yıldız T. (2013), Kastamonu Central District Analysis, North Anatolian Development Agency, [Internet]. Turkey; [cited 2018 June 10]. Available from: https://www.kuzka.gov.tr/Icerik/Dosya/www.kuzka.gov.tr_1 6_PO2G10AN_kastamonu_merkez_ilce_analizi.pdf.

Zhang F., Yan X., Zeng C., Zhang M., Shrestha S., Devkota L.P. and Yao T. (2012), Influence of traffic activity on heavy metal concentrations of roadside farmland soil in mountainous areas, International Journal of Environmental Research and Public Health, 9, 1715-1731; doi:10.3390/ijerph9051715. 